\title{
Effect of Crop Residues Incorporation on Physical Properties and Yield of Greengram-Safflower Crop Sequence under Sodic Haplusterts
}

\author{
R. T. Bhowate ${ }^{1 *}$ and P. H. Bansod ${ }^{2}$ \\ ${ }^{1}$ Cotton Research Unit, Dr. PDKV, Akola (M.S.) 444 104, India \\ ${ }^{2}$ Integrated Farming System, Dr. PDKV, Akola (M.S.) 444 104, India \\ *Corresponding author
}

\section{A B S T R A C T}

A field investigation was conducted during 2004-2005 at Karanja Ramzanpur, village in Purna valley in Vidarbha region. The experimental was laid out in Randomized Block Design, consisting of seven treatments i.e. $100 \%$ RD of NPK, $50 \%$ RD of NPK, PSB 10 $\mathrm{kg} \mathrm{ha}^{-1}$, crop residue @ $2 \mathrm{t} \mathrm{ha}^{-1}$ and alkali water irrigation passed through gypsum bed (30

\begin{tabular}{|l|}
\hline Keyw or d s \\
Sodic Haplusterts, \\
RD, PSB \\
\hline Article Info \\
\hline Accepted: \\
31 July 2017 \\
Available Online: \\
10 September 2017 \\
\hline
\end{tabular}
$\mathrm{cm}$ thickness). The initial $\mathrm{pHs}$, ECe, SAR and ESP representative soil varied from 8.51 to $8.40,1.06$ to $1.18,15.17$ to $9.22,18.36$ to 12.19 respectively. The results are present investigation revealed that alkali water irrigation passed through gypsum bed $(30 \mathrm{~cm}$ thickness) improved the quality of water before irrigation by reducing RSC and SAR from 19.11 to 5.47 and 13.75 to 8.46 . A significant highest total yield in both the crops were obtained as influenced by $100 \%$ RD of NPK alone, followed by $50 \%$ RD of NPK + PSB $10 \mathrm{~kg} \mathrm{ha}^{-1}+$ crop residue @ $2 \mathrm{t} \mathrm{ha}^{-1}$ with alkali water irrigation passed through gypsum bed (30 cm thickness). In combination with the application of $50 \%$ RD of NPK + PSB $10 \mathrm{~kg}$ $\mathrm{ha}^{-1}+$ crop @ $2 \mathrm{t} \mathrm{ha}^{-1}+$ alkali water irrigation passed through gypsum bed $(30 \mathrm{~cm}$ thickness) improved physical properties of Sodic Haplusterts decreased bulk density, increase hydraulic conductivity, infiltration rate, maximum water holding capacity and \% of water stable aggregate $>0.25 \mathrm{~mm}$. The composition of NPK nutrients and its uptake by greengram-safflower significantly increased in both the crops received under treatment $100 \%$ RD of NPK alone, followed by integrated 50 per cent RD of NPK + PSB $10 \mathrm{~kg} \mathrm{ha}^{-1}$ + crop residue@ $2 \mathrm{t} \mathrm{ha}^{-1}+$ alkali water irrigation passed through gypsum bed $(30 \mathrm{~cm}$ thickness).

\section{Introduction}

Purna Valley of Vidarbha region is the unique tract of Vertisols having native sodicity. It is east-west elongated basin with slight convexity to the south and extends from $20^{\circ} 45^{\prime}$ to $21^{0} 15^{\prime} \mathrm{N}$ latitude and $75^{\circ} 15^{\prime}$ to $77^{0} 45^{\prime} \mathrm{E}$ longitude with east-west length about $100-150 \mathrm{~km}$ and 10-60 $\mathrm{km}$ in width, covering an area about 4.49 lakh ha spread in 894 villages of Amravati, Akola and Buldana districts of Vidarbha (Govt. of Maharashtra,
2001). The development of salinity/sodicity in the basin is the natural and geological phenomenon, where the intensity of salinity/sodicity is comparatively less in surface layer, whereas, it increased with the depth of pedon. The salt affected Vertisols of some part of Purna Valley in Vidarbha having moderate to strong salinity and sodicity. These soils have high clay content, montmorillonitic mineralogy and swell shrink 
property and have very poor hydraulic conductivity. The major problems of these soils are very poor hydraulic conductivity, high degree of swell shrink potential, compact and dense soil fabric and incomplete leaching of salts in subsoil due to severe drainage impairment. The unique feature of these soils is that the salinity is widely reported in this area the presence of salt efflorescence on surface is hardly seen. However, use of well water which is alkali in nature makes situation more problematic. These soils have appreciable amount (5.01 to $17.50 \%$ ) of $\mathrm{CaCO}_{3}$ (Sagare et al., 1999). The precipitation of $\mathrm{Ca}$ in the form of $\mathrm{CaCO}_{3}$ greatly immobilizes $\mathrm{Ca}$ and $\mathrm{Mg}$ in these soils and dominance of $\mathrm{Na}$ is increased which ought to effect on physico-chemical properties of soil adversely. Such situation may enhance clay dispersion leading to destabilization of soil structure, breaking of soil capillary network and ultimately affecting negatively on water transmission characteristics of soil. Water is another problem of this area. The recent studies suggested that the ground water of valley is marginally alkali to alkali in nature (Sagare et al., 2000). Thus, reclamation and management of Sodic Haplusterts soil of Purna Valley has become important and urgent due to ever increasing pressure on land resources to meet food requirements and to mitigate the perils of irrigated agriculture. In India, reclamation much before any scientific knowledge on the nature and properties of these soils become actually available (Velayutham and Bhattacharya, 2000).

Reclamation of alkali soils requires replacement of $\mathrm{Na}$ by $\mathrm{Ca}$ through application of chemical amendments like gypsum, pyrite, press mud, organic and crop materials like crop residue, green manuring, etc. However, amongst the various amendments, gypsum found to be most effective for black clays. It can also be easily available and economically cheaper. In addition to this, irrigation water having high levels of RSC and SAR of $\mathrm{Mg}$ : $\mathrm{Ca}$ ratio or boron content, eliminated the bad effect of such water on soils and plants by passing it through gypsum bed.

\section{Material and Methods}

The field experiment was carried out during 2004-2005 at Karanja Ramzanpur, a village near Nimba phata, Taluka Balapur, District Akola situated in salt affected soil of Purna Valley. The site selected for field experiment is the representative site of Sodic Haplusterts. The Purna valley is a part of Payanghat plains is an oval or convex corner shaped basin along its western margin, as it enters the Tapi Valley. It covers the part of Amravati, Akola and Buldhana districts at the bank of Purna River having an area of about 4.49 lakhs ha in 894 villages. It is the area having native sodicity which increased with depth and it is almost becoming brine with depth (sodium chloride). This indicted that the Purna Valley sediments were earlier deposited in a salt water lake, which at least in the initial stage formed the part of Arabian Sea probably by extending its westerly arm.

The area has a monsoonal climate, with July through September receiving $85-95 \%$ of the total rainfall of $875-975 \mathrm{~mm}$. The region is one of the hottest in India with mean maximum temperature being $42.6^{\circ} \mathrm{C}$ during the month of May and mean minimum temperature being $10.5^{\circ} \mathrm{C}$ during month of December.

As per the criteria suggested by Keys to Soil Taxonomy (USDA, 1975) the pedon of experimental soil can be categorized as Sodic Haplusterts. The ground water of Purna Valley in Vidarbha region are marginally alkali to alkali nature (Sagare et al., 2000).

A field experiment in Randomized Block Design were seven treatments and three 
replication viz., $\mathrm{T}_{1} 100 \%$ RDF NPK without incorporation of crop residue, $\mathrm{T}_{2}$ Incorporation of crop residues @ $2 \mathrm{tha}^{-1} . \mathrm{T}_{3}$ PSB $10 \mathrm{~kg} \mathrm{ha}^{-1}+$ crop residue @ $2 \mathrm{t} \mathrm{ha}^{-1}+$ Alkali water irrigation passed through gypsum bed (30 cm thickness) for safflower only. $\mathrm{T}_{4} 50 \%$ RDF NPK with incorporation of crop residue @ $2 \mathrm{t} \mathrm{ha}^{-1} . \mathrm{T}_{5} 50 \% \mathrm{RDF} \mathrm{NPK}+$ PSB $10 \mathrm{~kg} \mathrm{ha}^{-1} . \mathrm{T}_{6} 50 \%$ RDF NPK + PSB 10 $\mathrm{kg} \mathrm{ha}{ }^{-1}+$ crop residue @ $2 \mathrm{t} \mathrm{ha}^{-1} \cdot \mathrm{T}_{7} 50 \%$ RDF NPK + PSB $10 \mathrm{~kg} \mathrm{ha}^{-1}$ + crop residue @ $2 \mathrm{t} \mathrm{ha}^{-1}+$ Alkali water irrigation passed through gypsum bed (30 cm thickness) for Safflower only. Incorporation of safflower crop residue before sowing of green gram and green gram crop residue was incorporated before safflower sowing. Rhizobium and Azotobacter was applied to greengram and safflower seeds respectively for all treatments. Irrigation with alkali water passed through specially designed tank (1m x $1 \mathrm{~m} \times$ $1 \mathrm{~m})$ filled with gypsum was given for treatment 3 and 7.

The height of gypsum bed was adjusted by placing $6 \mathrm{~mm}$ bar and iron net at 15 and 30 $\mathrm{cm}$ height. Irrigation was given by furrow method only safflower crop at critical stage i.e. 30 and 50 DAS. The recommended dose of fertilizer for greengram $20 \mathrm{~kg} \mathrm{~N}+40 \mathrm{~kg}$ $\mathrm{P}_{2} \mathrm{O}_{5} \mathrm{ha}^{-1}$ and safflower $40 \mathrm{~kg} \mathrm{~N}+40 \mathrm{~kg} \mathrm{P}_{2} \mathrm{O}_{5}$ ha $^{-1}$ was applied as per treatment. The treatments of crop residue incorporation was cut to small pieces $(10-15 \mathrm{~cm})$ and it was incorporated in $0-15 \mathrm{~cm}$ soil layers 30 days before sowing of crops.

Fertilizers used for the experiment were of commercial grade. Nitrogen, phosphorus applied through Urea and Single Super Phosphate, respectively. Soil samples collected before sowing and after harvest of each crop analyzed for soil texture, bulk density, hydraulic conductivity, maximum water holding capacity and per cent of water stable aggregate $>0.25 \mathrm{~mm}$. Bulk density was determined by core methods as described by Singh (1980). A cylindrical mettle sampler was pressed into the soil to the desire depth and carefully removed to preserve a known volume of sample, the sample was dried at $105^{\circ} \mathrm{C}$ to $110^{\circ} \mathrm{C}$ and weighted. Bulk density was calculated by using following formula.

$$
\begin{gathered}
\text { Weight of oven dry soil }(\mathrm{gm}) \\
\text { Bulk density }\left(\mathrm{Mg} \mathrm{m}^{-1}\right)=---{ }^{-} \\
\text {Volume of core or volume of field sample } \\
\left(\mathrm{cm}^{-3}\right)
\end{gathered}
$$

Infiltration was measured under each treatment plot of experimental soil using double ring infiltrometer method as described by Singh (1980). Water holding capacity was determined by using Keen Reckzonski boxes. Water stable aggregate Percentage of water stable aggregate of different size ranges and men weight diameter (MWD) were determined by Yoders wet sieving method (Singh, 1980)..

\section{Method of plant analysis}

Total nitrogen determined by Kjeldhal's digestion method as described by Piper (1966). Preparation of plant extract Di-acid extract of plant material and seed of crop samples by predigesting the seeds with concentrated $\mathrm{HNO}_{3}(5 \mathrm{ml}$ for each gm of seed sample) and then digested the content with a di-acid mixture of $\mathrm{HNO}_{3} ; \mathrm{HClO}_{4}$ in the proportion of $9: 4$ as described by Jackson (1967).

Total phosphorus it was estimated on spectrophotometer by Vandomolybdate yellow colour method (Jackson, 1967).Total potassium it was determined by flame photometer as described by Jackson (1967). Statistical analysis the level of statistical significance to the experimental data was carried out as per procedure described by Gomez and Gomez (1984). 


\section{Results and Discussion}

\section{Grain Yield of Green gram}

The data pertaining to grain and straw yield of greengram; presented in Table 3 revealed that there was significantly differences in yield of green gram due to various treatments. Maximum green gram grain yield $(9.04 \mathrm{q} \mathrm{ha}$

${ }^{1}$ ) was recorded due to application of 100 per cent recommended dose of fertilizer NPK through chemical fertilizer 20:40:00 $\left(\mathrm{T}_{1}\right)$ and it was found significantly superior over other treatment except treatment $\mathrm{T}_{7}\left(8.85 \mathrm{q} \mathrm{ha}^{-1}\right)$ i.e. application 50 per cent recommended dose of NPK + PSB $10 \mathrm{~kg} \mathrm{ha}^{-1}+$ crop residue @ $2 \mathrm{t}$ $\mathrm{ha}^{-1}$ with passing alkali water irrigation through gypsum bed of $30 \mathrm{~cm}$ thickness and it was found statistically at par to each other. The lowest yield of green gram $\left(4.45 \mathrm{q} \mathrm{ha}^{-1}\right)$ was recorded under treatment $T_{2}$ influenced by incorporation of crop residue @ $2 \mathrm{t} \mathrm{ha}^{-1}$ alone which indicates the need by application of inorganic fertilizer. Further, data it revealed that when the crop residue was applied, the grain yield of greengram were recorded 21.12, 30.32, 50.76 per cent more in treatment $\mathrm{T}_{4}, \mathrm{~T}_{6}$ and $\mathrm{T}_{7}$ respectively over the treatment $\mathrm{T}_{5}$ consisting 50\% RDF NPK + PSB $10 \mathrm{~kg} \mathrm{ha}^{-1}$. Conjunctive use of crop residue of safflower @ $2 \mathrm{t} \mathrm{ha}^{-1}$ along with of recommended level of fertilizer $\mathrm{N}$ and $\mathrm{P}$ improve productivity of crop.

\section{Straw Yield of green gram}

The application of 100 per cent recommended dose of NPK through chemical fertilizer gave significant highest straw yield of green gram in treatment $T_{1}\left(14.94 \mathrm{qha}^{-1}\right)$, and it was found statically at par with treatment $\mathrm{T}_{7}(13.81 \mathrm{q}$ ha $\left.{ }^{1}\right)$ with application of 50 per cent recommended dose of chemical fertilizer NPK + PSB $10 \mathrm{~kg} \mathrm{ha}^{-1}$ + crop residue @ $2 \mathrm{t}$ $\mathrm{ha}^{-1}$ with alkali water passed through gypsum bed of $30 \mathrm{~cm}$ thickness for irrigation. The application of biofertilizer without recommended dose of fertilizer increased the nodulation and fixing atmospheric nitrogen in soil. This was agreement with the result Rasal et al., (2003). The lowest straw yield was recorded in treatment T2 incorporation of crop residue@ $2 \mathrm{t} \mathrm{ha}^{-1}$ it was indicated that the application of chemical fertilizer alone or in combination for increasing the soil productivity similar results reported by Badanur et al., (2000).

\section{Seed Yield of Safflower}

The highest yield of safflower at application of 100 per cent recommended dose of fertilizer of NPK in treatment $T_{1}(11.72 \mathrm{q} \mathrm{ha}$ ${ }^{1}$ ) but it was found statistically at par with the treatment $\mathrm{T}_{7}\left(11.66 \mathrm{q} \mathrm{ha}^{-1}\right)$ consisting 50 per cent recommended dose of NPK + PSB + crop residue@2 t ha ${ }^{-1}$ and alkali water passed through gypsum bed of $30 \mathrm{~cm}$ thickness while irrigation. The improving the physic-chemical properties of Sodic Haplusters and reducing the detrimental effect of native sodicity of soil and ill effect of alkali water sounure (2002). The lowest yield (4.27 $\mathrm{q} \mathrm{ha}^{-1}$ ) of safflower was recorded in treatment receiving only crop residue @ $2 \mathrm{tha}^{-1}$ and no chemical fertilizer and irrigated with alkali water without gypsum bed in treatment $\left(\mathrm{T}_{2}\right)$.

\section{Straw Yield of Safflower}

The yield of safflower straw was influenced by different treatments the highest yield of straw was obtained with the use of 100 per cent recommended dose of NPK without incorporation of crop residue in treatment $T_{1}$ $\left(16.14 \mathrm{q} \mathrm{ha}^{-1}\right)$ and it was found at par with the treatment $\mathrm{T}_{7}\left(15.55 \mathrm{q} \mathrm{ha}^{-1}\right)$ with application of 50 per cent recommended dose of NPK + PSB $10 \mathrm{~kg} \mathrm{ha}^{-1}+$ crop residue @ $2 \mathrm{t} \mathrm{ha}^{-1}+$ alkali water passed through gypsum bed (30 $\mathrm{cm}$ thickness). Further, it revealed that when the crop residue was applied, the straw yield 
of safflower were recorded 6.92, and 18.94 per cent more in the treatment $\mathrm{T}_{6}$, and $\mathrm{T}_{7}$ respectively over the treatment $\mathrm{T}_{5}$ influenced by the $50 \%$ RDF NPK with PSB $10 \mathrm{~kg} \mathrm{ha}^{-1}$. Indicate that green gram residue incorporation with inorganic fertilizer significantly increased the yield of both crop as compared to only inorganic fertilizer. The lowest straw yield of safflower was found in treatment $T_{2}$ (9.56 q ha ${ }^{-1}$ ) with the incorporation of crop residue@ $2 \mathrm{tha}^{-1}$.

\section{Content of Nitrogen in greengram}

The results presented in Table 4 indicated that minimum $\mathrm{N}$ content in grain $(2.52 \%)$ and straw $(1.90 \%)$ was noticed treatment $\left(\mathrm{T}_{2}\right)$ only incorporation crop residue @ $2 \mathrm{t} \mathrm{ha}^{-1}$. Significantly highest $\mathrm{N}$ content in grain $(2.71 \%)$ and straw $(1.90 \%)$ in treatment $T_{1}$ and it was found statistically at par with treatment $\mathrm{T}_{7} \mathrm{~N}$ content in grain $(2.68 \%)$ and straw $(2.08 \%)$ in combination with 50 per cent RD of NPK + PSB $10 \mathrm{~kg} \mathrm{ha}^{-1}+$ crop residue@2 $\mathrm{t} \mathrm{ha}^{-1}+$ alkali water irrigation passed through gypsum bed of $30 \mathrm{~cm}$ thickness. An increased in $\mathrm{N}$ concentration might be due to increase in organic carbon content in soil as a results incorporation of crop residues and alkali water similar result also found by Swamy and Rao et al., (1991).

\section{Content of phosphorus}

The data showed $\mathrm{P}$ concentration in grain $(0.37 \%)$ and straw $(0.19 \%)$ was found lowest in treatment $\mathrm{T}_{2}$ only incorporation of crop residue@ $2 \mathrm{t} \mathrm{ha}^{-1}$ among all the treatments. The decrease in $\mathrm{P}$ content was probably caused by absorption of constitute ions from sodic medium, while resulted in toxic accumulation of some nutrients $(\mathrm{Na})$ and reduction of other nutrients in plant parts, in addition to this bicarbonate ions is directly related to the precipitation of $\mathrm{Ca}$ and $\mathrm{P}$ and thereby decrease their content. A decreased in phosphorus content in due to use of bicarbonate rich irrigation water was also reported by Paliwal et al., (1975). The highest $\mathrm{P}$ content in grain $(0.49 \%)$ and straw $(0.29 \%)$ and it was statistically at par with treatment $\mathrm{T}_{7}$. $\mathrm{N}$ content in grain $(0.47 \%)$ and straw $(0.27 \%)$ as influenced by 50 per cent RD of NPK + PSB $10 \mathrm{~kg} \mathrm{ha}^{-1}$ + crop residue @ $2 \mathrm{t}$ $\mathrm{ha}^{-1}+$ alkali water irrigation passed through gypsum bed of $30 \mathrm{~cm}$ thicken.

\section{Content of potassium}

From the data it was observed that the lowest $\mathrm{K}$ concentration in greengram grain (0.97) and straw $(1.92 \%)$ was received by treatment $\mathrm{T}_{2}$ (incorporation of crop residue @ $2 \mathrm{t} \mathrm{ha}^{-1}$ ). The lowest $\mathrm{K}$ content might be attribute due to antagonistic relationship of $\mathrm{Na}$ and $\mathrm{K}$ as alkali water and sodic soil are predominant by $\mathrm{Na}$. The adsorption of $\mathrm{Na}, \mathrm{K}, \mathrm{Ca}$ and $\mathrm{Mg}$ are mostly governed by their respective status in the exchangeable phase of soil and soil solution. Since soils irrigated with high $\mathrm{Na}$ content of irrigation water contains more of $\mathrm{Na}$ in the exchange complex, adsorption of $\mathrm{Na}$ increase and other nutrients decrease similar result also found by Ali and Pathak,1991. The potassium content in greengram grain $(1.19 \%)$ and straw $(2.24 \%)$ was found significantly highest in the treatment $T_{1}$ due to application 100 per cent RD of NPK and it was found statistically at par with the treatment $\mathrm{T}_{7}$ in grain $(1.18 \%)$ and straw $(2.21 \%)$ in combination with 50 per cent RD of NPK+ PSB $10 \mathrm{~kg} \mathrm{ha}^{-1}+$ crop residue@ $2 \mathrm{t} \mathrm{ha}^{-1}+$ alkali water irrigation passed through gypsum bed of $30 \mathrm{~cm}$ thickness.

\section{Uptake of Nitrogen by green gram}

Nitrogen is an essential constituent of protein, chlorophyll, amino acids, alkaloids and protoplasm. It promotes vegetative growth, induces dark green colour to foliage and give 
succulent appearance to plants. The results in respect to $\mathrm{N}$ uptake by greengram grain and straw at harvest was recorded and presented in Table 5 Nitrogen uptake was significantly influenced by various treatments. The uptake of nitrogen by grain and straw was found significantly increased in treatment $\mathrm{T}_{1}$ (24.49 and $31.52 \mathrm{~kg} \mathrm{~N} \mathrm{ha}^{-1}$ ) application only 100 per cent RD of NPK without incorporation of crop residue was applied and it was found at par with the treatment $\mathrm{T}_{7}(23.71$ and $28.73 \mathrm{~kg}$ $\mathrm{N} \mathrm{ha}^{-1}$ ) as influenced by 50 per cent RD of NPK + PSB $10 \mathrm{~kg} \mathrm{ha}^{-1}$ + crop residue @ $2 \mathrm{t}$ $\mathrm{ha}^{-1}+$ alkali water irrigation passed through gypsum bed of $30 \mathrm{~cm}$ thickness. Since, total biomass was more these treatments, total uptake was increased as compared to treatment $\mathrm{T}_{2} \quad\left(27.86 \mathrm{~kg} \quad \mathrm{~N} \quad \mathrm{ha}^{-1}\right)$ with incorporation crop residue @ $2 \mathrm{t} \mathrm{ha}^{-1}$ only without inorganic fertilizer. It caused the fixation of atmospheric $\mathrm{N}$ and better utilization of soil available $\mathrm{N}$ by green gram. It is well known that phosphorus enhances the activity of rhizobia and increase nodulation in legumes. Amount of nitrogen fixed by rhizobium in greengram similar result also found by (Subbarao, 1987).

\section{Uptake of phosphorus by Greengram}

It is well known that phosphorus is actively involved in carbohydrate metabolism, biochemical and energy transformation and respiration. It stimulates root development, gives strength to straw and counteract the effects of excessive nitrogen and enhanced the activity of rhizobia. The data concerning to $\mathrm{P}$ uptake by green gram is presented in Table 5 revealed that highest $\mathrm{P}$ uptake by grain was recorded by treatment $\mathrm{T}_{1}$ (grain $4.42 \mathrm{~kg} \mathrm{P} \mathrm{ha}^{-1}$ ), (straw $4.42 \mathrm{~kg} \mathrm{P} \mathrm{ha}^{-1}$ ) as influenced by 100 per cent RD of NPK without incorporation crop residue and it was found at par with the treatment $\mathrm{T}_{7}$ (grain $4.15 \mathrm{~kg} \quad \mathrm{P} \quad \mathrm{ha}^{-1}$ ) (straw $4.15 \quad \mathrm{~kg} \quad \mathrm{P} \quad \mathrm{ha}^{-}$ 1) application of 50 per cent RD of NPK+ PSB
$10 \mathrm{~kg} \mathrm{ha}^{-1}+$ crop residue @ $2 \mathrm{t} \mathrm{ha}^{-1}+$ alkali water irrigation passed through gypsum bed of $30 \mathrm{~cm}$ thickness. The lowest $\mathrm{P}$ uptake by green gram was observed in treatment $T_{2}$ (grain $\left.1.65 \mathrm{~kg} \mathrm{P} \mathrm{ha}^{-1}\right),\left(1.62 \mathrm{~kg} \mathrm{P} \mathrm{ha}^{-1}\right)$ i.e. Incorporation of crop residue @ $2 \mathrm{tha}^{-1}$.

\section{Potassium uptake by greengram}

Potassium is an activator for enzyme involved in protein synthesis, carbohydrate and nucleic acid metabolism. It does not enter into composition of any plant constituents but impact vigour and disease resistance to plant and produce stiff-straw, Huber (1985) has reported the effect of $\mathrm{K}$ on growth, deficiency of which resulted carbon assimilation and leaf area. Hence, it is necessary to take into account the utilization of $\mathrm{K}$ by influenced by various treatments.

Potassium uptake by green gram grain was significantly as influenced by various treatments. Higher $\mathrm{K}$ uptake by grain was found in treatment $\mathrm{T}_{1}$ (grain $10.75 \mathrm{~kg} \mathrm{~K} \mathrm{ha}^{-1}$ ) and straw (33.46 kg K ha ${ }^{-1}$ ) as influence by 100 per cent RD of NPK without incorporation crop residue and was found statistically at par with treatment $\mathrm{T}_{7}$ (grain $10.43 \mathrm{~kg} \mathrm{~K} \mathrm{ha}^{-1}$ ) and straw (30.52 $\mathrm{kg} \mathrm{K} \mathrm{ha}^{-1}$ ) (Table 5) received under 50 per cent $\mathrm{RD}$ of NPK+ PSB $10 \mathrm{~kg} \mathrm{ha}^{-1}+$ crop residue @ 2 ha $^{-1}$ + alkali water irrigation passed through gypsum bed of $30 \mathrm{~cm}$ thickness.

The lowest uptake of potassium was noticed in treatment $\mathrm{T}_{2}$ (grain $4.31 \mathrm{~kg} \mathrm{~K} \mathrm{ha}{ }^{-1}$ ) and straw $\left(16.83 \mathrm{~kg} \mathrm{~K} \mathrm{ha}^{-1}\right)$ due to incorporation of crop residue@2 $\mathrm{t} \mathrm{ha}^{-1}$. An increase in $\mathrm{K}$ uptake due to gypsum application which supply calcium might be attributed to calcium preventing the uptake of $\mathrm{Na}$ ions to injurious level and allowing the uptake of K (Waisel, 1962). Similar increase in K uptake was also recorded by Poonia and Bhumbla (1973 a, 1973 b). 
Table.1 Initial physico-chemical characteristics of experimental soil

\begin{tabular}{|c|c|c|c|c|}
\hline \multirow{2}{*}{$\begin{array}{l}\text { Sr. } \\
\text { No. }\end{array}$} & \multirow[t]{2}{*}{ Characteristics } & \multicolumn{3}{|c|}{ Soil depth $(\mathrm{cm})$} \\
\hline & & 0-30 & $30-60$ & $60-90$ \\
\hline \multicolumn{5}{|c|}{ Mechanical analysis } \\
\hline & \multicolumn{4}{|l|}{ Particle size distribution } \\
\hline 1 & Sand $(\%)$ & 6.30 & 4.73 & 4.17 \\
\hline 2 & Silt (\%) & 28.43 & 27.75 & 27.48 \\
\hline 3 & Clay $(\%)$ & 65.27 & 67.52 & 68.35 \\
\hline \multicolumn{5}{|c|}{ Physical properties } \\
\hline 1 & Bulk Density $\left(\mathrm{Mg} \mathrm{m}^{-3}\right)$ & 1.51 & 1.60 & 1.82 \\
\hline 2 & Hydraulic conductivity $\left(\mathrm{cm} \mathrm{hr}^{-1}\right)$ & 0.14 & 0.13 & 0.11 \\
\hline \multicolumn{5}{|c|}{ Chemical properties } \\
\hline 1 & pHs & 8.49 & 8.59 & 8.72 \\
\hline 2 & $\operatorname{ECe}\left(\mathrm{dS} \mathrm{m}^{-1}\right)$ & 1.04 & 1.18 & 1.27 \\
\hline 3 & $\mathrm{CaCo}_{3}(\%)$ & 12.30 & 13.52 & 14.27 \\
\hline \multicolumn{5}{|c|}{ Water soluble cations $\left(\mathrm{meq} \mathbf{L}^{-1}\right)$} \\
\hline 1 & $\mathrm{Ca}^{++}$ & 1.63 & 1.97 & 3.04 \\
\hline 2 & $\mathrm{Mg}^{++}$ & 0.65 & 1.21 & 2.33 \\
\hline 3 & $\mathrm{Na}^{+}$ & 15.69 & 21.78 & 26.72 \\
\hline \multicolumn{5}{|c|}{ Water soluble anions $\left(\mathrm{mq} \mathrm{L}^{-1}\right)$} \\
\hline 1 & $\mathrm{CO}_{3}$ & 4.23 & 5.18 & 5.38 \\
\hline 2 & $\mathrm{HCO}_{3}$ & 4.80 & 6.65 & 12.35 \\
\hline 3 & $\mathrm{SO}_{4}^{--}$ & 0.17 & 0.38 & 0.61 \\
\hline 4 & SAR & 13.63 & 14.47 & 16.41 \\
\hline \multicolumn{5}{|c|}{ Exchangeable cations $\left(\mathrm{cmol}\left(\mathrm{P}^{+}\right) \mathrm{kg}^{-1}\right)$} \\
\hline 1 & $\mathrm{Ca}^{++}$ & 36.15 & 38.35 & 37.30 \\
\hline 2 & $\mathrm{Mg}^{++}$ & 15.80 & 14.22 & 10.50 \\
\hline 3 & $\mathrm{Na}^{+}$ & 9.05 & 11.56 & 12.28 \\
\hline 4 & $\mathrm{~K}^{+}$ & 1.48 & 1.61 & 1.33 \\
\hline 5 & ESP & 16.40 & 18.72 & 19.17 \\
\hline I & Organic carbon $\left(\mathrm{g} \mathrm{kg}^{-1}\right)$ & 4.22 & 3.64 & 2.49 \\
\hline II & Available $\mathrm{N}\left(\mathrm{kg} \mathrm{ha}^{-1}\right)$ & 175.33 & 125.72 & 89.95 \\
\hline III & Available $\mathrm{P}_{2} \mathrm{O}_{5}\left(\mathrm{~kg} \mathrm{ha}^{-1}\right)$ & 29.06 & 16.41 & 13.34 \\
\hline VI) & Available $\mathrm{K}_{2} \mathrm{O}\left(\mathrm{kg} \mathrm{ha}^{-1}\right)$ & 427.59 & 368.17 & 320.92 \\
\hline
\end{tabular}

Table.2 Effect of Gypsum bed (30 cm thickness) on chemical composition of alkali water used for irrigation

\begin{tabular}{|c|c|c|c|c|c|c|c|c|c|c|c|c|}
\hline \multirow{2}{*}{$\begin{array}{l}\text { Sr. } \\
\text { No. }\end{array}$} & \multirow[t]{2}{*}{ Treatment } & \multirow[t]{2}{*}{ PHiw } & \multirow{2}{*}{$\begin{array}{l}\text { ECiw } \\
\left(\mathrm{dSm}^{-1}\right)\end{array}$} & \multicolumn{4}{|c|}{ Anion $\left(\operatorname{meq} L^{-1}\right)$} & \multicolumn{3}{|c|}{ Cation $\left(m e q L^{-1}\right)$} & \multirow[t]{2}{*}{ SAR } & \multirow[t]{2}{*}{ RSC } \\
\hline & & & & $\mathrm{CO}_{3}$ & $\mathrm{HCO}_{3}$ & $\mathrm{Cl}$ & $\mathrm{SO}_{4}$ & $\mathbf{C a}$ & Mg & $\mathbf{N a}$ & & \\
\hline 1. & $\begin{array}{l}\text { Initial chemical } \\
\text { composition of tube } \\
\text { well water }\end{array}$ & 8.75 & 1.88 & 0.58 & 12.28 & 3.91 & 2.12 & 1.85 & 0.90 & 16.13 & 13.75 & 10.11 \\
\hline 2. & $\begin{array}{l}\text { Chemical } \\
\text { composition of tube } \\
\text { well water passed } \\
\text { through gypsum bed }\end{array}$ & 8.64 & 2.25 & 0.51 & 11.82 & 3.50 & 6.69 & 5.63 & 1.23 & 15.67 & 8.46 & 5.47 \\
\hline
\end{tabular}


Table.3 Effect of different treatments on grain and straw yield of green gram and safflower

\begin{tabular}{|c|c|c|c|c|c|}
\hline \multirow{2}{*}{\multicolumn{2}{|c|}{ Treatment }} & \multicolumn{2}{|c|}{$\begin{array}{l}\text { Greengram (q } \\
\mathrm{ha}^{-1} \text { ) }\end{array}$} & \multicolumn{2}{|c|}{$\begin{array}{l}\text { Safflower (q ha } \\
\text { 1) }\end{array}$} \\
\hline & & Grain & Straw & Seed & Straw \\
\hline $\mathrm{T}_{1}$ & $100 \%$ RDF NPK without incorporation of crop residue & 9.04 & 11.72 & 16.14 & 14.94 \\
\hline $\mathrm{T}_{2}$ & Incorporation of crop residue @ $2 \mathrm{t} \mathrm{ha}^{-1}$ & 4.45 & 4.27 & 9.56 & 8.76 \\
\hline $\mathrm{T}_{3}$ & $\begin{array}{l}\text { PSB } 10 \mathrm{~kg} \mathrm{ha}^{-1}+\text { crop residue @ } 2 \mathrm{tha}^{-1}+\text { Alkali water } \\
\text { irrigation passed through gypsum bed }(30 \mathrm{~cm}\end{array}$ & 5.87 & 5.96 & 11.15 & 11.67 \\
\hline $\mathrm{T}_{4}$ & $50 \%$ RDF NPK with incorporation of crop residue @ 2 & 7.11 & 9.89 & 14.29 & 12.08 \\
\hline $\mathrm{T}_{5}$ & $50 \%$ RDF NPK + PSB $10 \mathrm{~kg} \mathrm{ha}^{-1}$ & 6.26 & 9.82 & 13.36 & 12.45 \\
\hline $\mathrm{T}_{6}$ & $\begin{array}{l}\text { 50\% RDF NPK + PSB } 10 \mathrm{~kg} \mathrm{ha}^{-1}+\text { crop residue @ } 2 \mathrm{t} \\
\mathrm{ha}^{-1}\end{array}$ & 7.65 & 10.50 & 14.71 & 13.45 \\
\hline $\mathrm{T}_{7}$ & $\begin{array}{l}50 \% \text { RDF NPK + PSB } 10 \mathrm{~kg} \mathrm{ha}^{-1}+\text { crop residue @ } 2 \mathrm{t} \\
\text { ha }^{-1}+\text { Alkali water irrigation passed through gypsum } \\
\text { hed }\end{array}$ & 8.85 & 11.66 & 15.55 & 13.81 \\
\hline \multicolumn{2}{|r|}{ 'F' test } & Sig. & Sig. & Sig. & Sig. \\
\hline \multicolumn{2}{|c|}{$\mathrm{SE}(\mathrm{m}) \pm$} & 0.20 & 0.38 & 0.42 & 0.37 \\
\hline \multicolumn{2}{|c|}{ C.D. at $5 \%$} & 0.56 & 1.08 & 1.24 & 1.04 \\
\hline
\end{tabular}

Table.4 NPK content (\%) in Greengram as influenced by different treatments

\begin{tabular}{|c|c|c|c|c|c|c|c|}
\hline \multirow{2}{*}{\multicolumn{2}{|c|}{ Treatments }} & \multicolumn{2}{|c|}{$\begin{array}{ll}\mathbf{N} & \text { content } \\
(\%) & \end{array}$} & \multicolumn{2}{|c|}{$\begin{array}{ll}\text { P } & \text { content } \\
(\%) & \end{array}$} & \multicolumn{2}{|c|}{$K$ content $(\%)$} \\
\hline & & Grain & Straw & Grain & Straw & Grain & Straw \\
\hline $\mathrm{T}_{1}$ & $\begin{array}{l}100 \% \text { RDF NPK without incorporation } \\
\text { of crop residue }\end{array}$ & 2.71 & 2.11 & 0.49 & 0.29 & 1.19 & 2.24 \\
\hline $\mathrm{T}_{2}$ & Incorporation of crop residue @ $2 \mathrm{t} \mathrm{ha}^{-1}$ & 2.52 & 1.90 & 0.37 & 0.19 & 0.97 & 1.92 \\
\hline $\mathrm{T}_{3}$ & $\begin{array}{l}\text { PSB } 10 \mathrm{~kg} \mathrm{ha}^{-1}+\text { crop residue @ } 2 \mathrm{t} \mathrm{ha}^{-1} \\
+ \text { Alkali water irrigation passed through } \\
\text { gypsum bed }(30 \mathrm{~cm} \text { thickness }) \text { for } \\
\text { safflower only }\end{array}$ & 2.55 & 1.92 & 0.40 & 0.21 & 1.04 & 2.05 \\
\hline $\mathrm{T}_{4}$ & $\begin{array}{l}50 \% \text { RDF NPK with incorporation of } \\
\text { crop residue @ } 2 \mathrm{tha}^{-1}\end{array}$ & 2.61 & 1.99 & 0.42 & 0.23 & 1.09 & 2.09 \\
\hline $\mathrm{T}_{5}$ & $50 \%$ RDF NPK + PSB $10 \mathrm{~kg} \mathrm{ha}^{-1}$ & 2.59 & 1.97 & 0.44 & 0.25 & 1.01 & 1.94 \\
\hline $\mathrm{T}_{6}$ & $\begin{array}{l}50 \% \text { RDF NPK + PSB } 10 \mathrm{~kg} \mathrm{ha}^{-1}+\text { crop } \\
\text { residue @ } 2 \mathrm{t} \mathrm{ha}^{-1}\end{array}$ & 2.62 & 2.05 & 0.45 & 0.26 & 1.11 & 2.17 \\
\hline $\mathrm{T}_{7}$ & $\begin{array}{l}50 \% \text { RDF NPK + PSB } 10 \mathrm{~kg} \mathrm{ha}^{-1}+\text { crop } \\
\text { residue @ } 2 \mathrm{t} \mathrm{ha}^{-1}+\text { Alkali water } \\
\text { irrigation passed through gypsum bed } \\
(30 \mathrm{~cm} \text { thickness }) \text { for safflower only }\end{array}$ & 2.68 & 2.08 & 0.47 & 0.27 & 1.18 & 2.21 \\
\hline \multicolumn{2}{|r|}{ ' $F$ ' test } & Sig. & Sig. & sig. & sig. & Sig. & Sig. \\
\hline \multicolumn{2}{|c|}{$\mathrm{SE}(\mathrm{m}) \pm$} & 0.01 & 0.01 & 0.013 & 0.01 & 0.011 & 0.012 \\
\hline \multicolumn{2}{|c|}{ C.D. at $5 \%$} & 0.03 & 0.029 & 0.039 & 0.03 & 0.033 & 0.034 \\
\hline
\end{tabular}


Table.5 Effect of different treatments on NPK uptake by green gram $\mathrm{kg} \mathrm{ha}^{-1}$

\begin{tabular}{|c|c|c|c|c|c|c|c|}
\hline \multirow{2}{*}{\multicolumn{2}{|c|}{ Treatments }} & \multicolumn{2}{|c|}{$\begin{array}{l}\mathrm{N} \text { uptake } \mathrm{kg} \\
\mathrm{ha}^{-1}\end{array}$} & \multicolumn{2}{|c|}{$\begin{array}{l}\mathrm{P} \text { uptake } \mathrm{kg} \\
\mathrm{ha}^{-1}\end{array}$} & \multicolumn{2}{|c|}{$\begin{array}{l}\mathrm{K} \text { uptake } \mathrm{kg} \\
\mathrm{ha}^{-1}\end{array}$} \\
\hline & & Grain & Straw & Grain & Straw & Grain & Straw \\
\hline $\mathrm{T}_{1}$ & $\begin{array}{l}100 \% \text { RDF NPK without incorporation of } \\
\text { crop residue }\end{array}$ & 24.49 & 31.52 & 4.42 & 4.34 & 10.75 & 33.46 \\
\hline $\mathrm{T}_{2}$ & Incorporation of crop residue @ $2 \mathrm{t} \mathrm{ha}^{-1}$ & 11.21 & 16.65 & 1.65 & 1.62 & 4.31 & 16.81 \\
\hline $\mathrm{T}_{3}$ & $\begin{array}{l}\text { PSB } 10 \mathrm{~kg} \mathrm{ha}^{-1}+\text { crop residue @ } 2 \mathrm{t} \mathrm{ha}^{-1}+ \\
\text { Alkali water irrigation passed through } \\
\text { gypsum bed }(30 \mathrm{~cm} \text { thickness) for safflower } \\
\text { only }\end{array}$ & 14.96 & 22.40 & 2.47 & 2.45 & 6.10 & 23.91 \\
\hline $\mathrm{T}_{4}$ & $\begin{array}{l}50 \% \text { RDF NPK with incorporation of crop } \\
\text { residue @ } 2 \mathrm{t} \mathrm{ha}^{-1}\end{array}$ & 18.55 & 24.04 & 2.99 & 2.77 & 7.75 & 25.24 \\
\hline $\mathrm{T}_{5}$ & $50 \%$ RDF NPK + PSB $10 \mathrm{~kg} \mathrm{ha}^{-1}$ & 16.21 & 13.89 & 2.75 & 3.11 & 6.32 & 24.15 \\
\hline $\mathrm{T}_{6}$ & $\begin{array}{l}50 \% \text { RDF } \mathrm{NPK}+\text { PSB } 10 \mathrm{~kg} \mathrm{ha}^{-1}+\text { crop } \\
\text { residue @ } 2 \mathrm{t} \mathrm{ha}^{-1}\end{array}$ & 20.04 & 27.57 & 3.44 & 3.49 & 8.49 & 29.19 \\
\hline $\mathrm{T}_{7}$ & $\begin{array}{l}50 \% \text { RDF NPK + PSB } 10 \mathrm{~kg} \mathrm{ha}^{-1}+\text { crop } \\
\text { residue @ } 2 \mathrm{t} \mathrm{ha}^{-1}+\text { Alkali water irrigation } \\
\text { passed through gypsum bed }(30 \mathrm{~cm} \\
\text { thickness) for safflower only }\end{array}$ & 23.71 & 28.73 & 4.15 & 3.81 & 10.43 & 30.53 \\
\hline \multicolumn{2}{|r|}{ 'F' test } & Sig. & Sig. & Sig. & Sig. & Sig. & Sig. \\
\hline \multicolumn{2}{|c|}{$\mathrm{SE}(\mathrm{m}) \pm$} & 0.54 & 0.78 & 0.14 & 0.20 & 0.22 & 0.80 \\
\hline \multicolumn{2}{|c|}{ C.D. at $5 \%$} & 1.53 & 2.33 & 0.40 & 0.64 & 0.69 & 2.26 \\
\hline
\end{tabular}

Table.6 NPK content (\%) in Safflower as influenced by different treatments

\begin{tabular}{|c|c|c|c|c|c|c|c|}
\hline \multirow{2}{*}{\multicolumn{2}{|c|}{ Treatments }} & \multicolumn{2}{|c|}{$\begin{array}{ll}\mathrm{N} & \text { content } \\
(\%) & \\
\end{array}$} & \multicolumn{2}{|c|}{$\mathrm{P}$ content $(\%)$} & \multicolumn{2}{|c|}{$\begin{array}{ll}\mathrm{K} & \text { content } \\
(\%) & \end{array}$} \\
\hline & & Grain & Straw & Grain & Straw & Grain & Straw \\
\hline $\mathrm{T}_{1}$ & $100 \%$ RDF NPK without incorporation of & 2.39 & 1.37 & 0.68 & 0.23 & 0.89 & 1.72 \\
\hline $\mathrm{T}_{2}$ & Incorporation of crop residue @2 $\mathrm{t} \mathrm{ha}^{-1}$ & 2.05 & 1.21 & 0.50 & 0.13 & 0.75 & 1.51 \\
\hline $\mathrm{T}_{3}$ & $\begin{array}{l}\text { PSB } 10 \mathrm{~kg} \mathrm{ha}^{-1}+\text { crop residue @ } 2 \mathrm{t} \mathrm{ha}^{-1}+ \\
\text { Alkali water irrigation passed through } \\
\text { gypsum bed }(30 \mathrm{~cm} \text { thickness }) \text { for safflower }\end{array}$ & 2.20 & 1.25 & 0.55 & 0.16 & 0.80 & 1.60 \\
\hline $\mathrm{T}_{4}$ & $\begin{array}{l}50 \% \text { RDF NPK with incorporation of crop } \\
\text { residue @ } 2 \mathrm{t} \mathrm{ha}^{-1}\end{array}$ & 2.18 & 1.27 & 0.57 & 0.18 & 0.83 & 1.62 \\
\hline $\mathrm{T}_{5}$ & $50 \%$ RDF NPK + PSB $10 \mathrm{~kg} \mathrm{ha}^{-1}$ & 2.24 & 1.26 & 0.53 & 0.20 & 0.83 & 1.65 \\
\hline $\mathrm{T}_{6}$ & $\begin{array}{l}50 \% \text { RDF NPK + PSB } 10 \mathrm{~kg} \mathrm{ha}^{-1}+\text { crop } \\
\text { residue @ } 2 \mathrm{t} \mathrm{ha}^{-1}\end{array}$ & 2.31 & 1.33 & 0.60 & 0.19 & 0.86 & 1.68 \\
\hline $\mathrm{T}_{7}$ & $\begin{array}{l}50 \% \text { RDF NPK + PSB } 10 \mathrm{~kg} \mathrm{ha}^{-1}+\text { crop } \\
\text { residue @ } 2 \mathrm{t} \mathrm{ha}^{-1}+\text { Alkali water irrigation } \\
\text { passed through gypsum bed }(30 \mathrm{~cm} \\
\text { thickness) for safflower only }\end{array}$ & 2.37 & 1.35 & 0.64 & 0.21 & 0.87 & 1.70 \\
\hline \multicolumn{2}{|r|}{ 'F' test } & Sig. & Sig. & Sig. & Sig. & Sig. & Sig. \\
\hline \multicolumn{2}{|c|}{$\mathrm{SE}(\mathrm{m}) \pm$} & 0.010 & 0.014 & 0.011 & 0.014 & 0.014 & 0.016 \\
\hline \multicolumn{2}{|c|}{ C.D. at $5 \%$} & 0.030 & 0.041 & 0.031 & 0.040 & 0.041 & 0.045 \\
\hline
\end{tabular}


Table.7 Effect of different treatments on NPK uptake by safflower kg ha ${ }^{-1}$

\begin{tabular}{|c|c|c|c|c|c|c|c|}
\hline \multirow{2}{*}{\multicolumn{2}{|c|}{ Treatments }} & \multicolumn{2}{|c|}{$\mathrm{N}$ uptake $\mathrm{kg} \mathrm{ha}^{-1}$} & \multicolumn{2}{|c|}{ P uptake $\mathrm{kg} \mathrm{ha}^{-1}$} & \multicolumn{2}{|c|}{$\mathrm{N}$ uptake $\mathrm{kg} \mathrm{ha}{ }^{-1}$} \\
\hline & & \multirow{2}{*}{$\frac{\text { Grain }}{28.68}$} & \multirow{2}{*}{$\frac{\text { Straw }}{22.09}$} & \multirow{2}{*}{$\begin{array}{l}\text { Grain } \\
7.97\end{array}$} & \multirow{2}{*}{$\frac{\text { Straw }}{3.71}$} & \multirow{2}{*}{$\begin{array}{c}\text { Grain } \\
10.43\end{array}$} & \multirow{2}{*}{$\frac{\text { Straw }}{27.75}$} \\
\hline $\mathrm{T}_{1}$ & $\begin{array}{l}100 \% \text { RDF NPK without incorporation of } \\
\text { crop residue }\end{array}$ & & & & & & \\
\hline $\mathrm{T}_{2}$ & Incorporation of crop residue @ $2 \mathrm{t} \mathrm{ha}^{-1}$ & 8.75 & 11.57 & 2.13 & 1.25 & 3.18 & 14.41 \\
\hline $\mathrm{T}_{3}$ & $\begin{array}{l}\text { PSB } 10 \mathrm{~kg} \mathrm{ha}^{-1}+\text { crop residue @ } 2 \mathrm{tha}^{-1}+ \\
\text { Alkali water irrigation passed through } \\
\text { gypsum bed }(30 \quad \mathrm{~cm} \text { thickness }) \text { for } \\
\text { safflower only }\end{array}$ & 13.11 & 13.92 & 3.27 & 1.78 & 4.76 & 17.83 \\
\hline $\mathrm{T}_{4}$ & $\begin{array}{l}50 \% \text { RDF NPK with incorporation of crop } \\
\text { residue @ } 2 \mathrm{t} \mathrm{ha}^{-1}\end{array}$ & 21.48 & 18.14 & 5.62 & 2.57 & 8.21 & 23.14 \\
\hline $\mathrm{T}_{5}$ & $50 \%$ RDF NPK + PSB $10 \mathrm{~kg} \mathrm{ha}^{-1}$ & 22.00 & 16.82 & 5.19 & 2.68 & 8.26 & 22.04 \\
\hline $\mathrm{T}_{6}$ & $\begin{array}{l}50 \% \text { RDF NPK + PSB } 10 \mathrm{~kg} \mathrm{ha}^{-1}+\text { crop } \\
\text { residue @ } 2 \mathrm{t} \mathrm{ha}^{-1}\end{array}$ & 24.25 & 19.55 & 6.29 & 2.79 & 9.02 & 24.70 \\
\hline $\mathrm{T}_{7}$ & $\begin{array}{l}50 \% \text { RDF NPK + PSB } 10 \mathrm{~kg} \mathrm{ha}^{-1}+\text { crop } \\
\text { residue @ } 2 \mathrm{t} \mathrm{ha}^{-1}+\text { Alkali water irrigation } \\
\text { passed through gypsum bed }(30 \mathrm{~cm} \\
\text { thickness) for safflower only }\end{array}$ & 27.62 & 20.98 & 7.41 & 3.25 & 10.08 & 26.76 \\
\hline \multicolumn{2}{|r|}{ 'F' test } & Sig. & Sig. & Sig. & Sig. & Sig. & Sig. \\
\hline \multicolumn{2}{|c|}{$\mathrm{SE}(\mathrm{m}) \pm$} & 0.77 & 0.43 & 0.22 & 0.23 & 0.35 & 0.61 \\
\hline \multicolumn{2}{|c|}{ C.D. at $5 \%$} & 2.16 & 1.22 & 0.68 & 0.67 & 1.08 & \\
\hline
\end{tabular}

Table.8 Effect of different treatments on physical properties of soil at harvest of safflower

\begin{tabular}{|c|c|c|c|c|c|c|}
\hline \multicolumn{2}{|c|}{ Treatment } & $\begin{array}{l}\text { Bulk } \\
\text { Density } \\
\left(\mathrm{Mgm}^{-3}\right)\end{array}$ & $\begin{array}{l}\text { Hydraulic } \\
\text { condu-ctivity } \\
\left(\mathrm{cm} \mathrm{hr}^{-1}\right)\end{array}$ & $\begin{array}{l}\text { Infiltration } \\
\text { rate }\left(\mathrm{cm} \mathrm{hr}^{-1}\right)\end{array}$ & $\begin{array}{l}\text { Max. water } \\
\text { holding } \\
\text { capacity } \\
(\%)\end{array}$ & $\begin{array}{l}\text { Water stable } \\
\text { aggregate of } \\
>0.25 \mathrm{~mm} \\
(\%)\end{array}$ \\
\hline $\mathrm{T}_{1}$ & $\begin{array}{l}100 \% \text { RDF NPK without } \\
\text { incorporation of crop residue }\end{array}$ & 1.51 & 0.15 & 1.23 & 51.35 & 46.23 \\
\hline $\mathrm{T}_{2}$ & $\begin{array}{l}\text { Incorporation of crop residue @ } 2 \mathrm{t} \\
\mathrm{ha}^{-1}\end{array}$ & 1.50 & 0.20 & 1.41 & 52.48 & 47.81 \\
\hline $\mathrm{T}_{3}$ & $\begin{array}{l}\text { PSB } 10 \mathrm{~kg} \mathrm{ha}^{-1}+\text { crop residue @ } 2 \mathrm{t} \\
\mathrm{ha}^{-1}+\text { Alkali water irrigation passed } \\
\text { through gypsum bed }(30 \mathrm{~cm} \\
\text { thickness }) \text { for safflower only }\end{array}$ & 1.40 & 0.24 & 1.66 & 53.70 & 49.25 \\
\hline $\mathrm{T}_{4}$ & $\begin{array}{l}50 \% \text { RDF NPK with incorporation } \\
\text { of crop residue @ } 2 \mathrm{t} \mathrm{ha}^{-1}\end{array}$ & 1.43 & 0.28 & 1.69 & 55.69 & 47.10 \\
\hline $\mathrm{T}_{5}$ & $50 \%$ RDF NPK + PSB $10 \mathrm{~kg} \mathrm{ha}^{-1}$ & 1.45 & 0.18 & 1.36 & 51.98 & 49.85 \\
\hline $\mathrm{T}_{6}$ & $\begin{array}{l}50 \% \text { RDF NPK + PSB } 10 \mathrm{~kg} \mathrm{ha}^{-1}+ \\
\text { crop residue @ } 2 \mathrm{t} \mathrm{ha}^{-1}\end{array}$ & 1.42 & 0.30 & 1.72 & 57.15 & 51.26 \\
\hline $\mathrm{T}_{7}$ & $\begin{array}{l}50 \% \text { RDF NPK + PSB } 10 \mathrm{~kg} \mathrm{ha}^{-1}+ \\
\text { crop residue @ } 2 \mathrm{t} \mathrm{ha}^{-1}+\text { Alkali } \\
\text { water irrigation passed through } \\
\text { gypsum bed }(30 \mathrm{~cm} \text { thickness) for } \\
\text { safflower only }\end{array}$ & 1.39 & 0.33 & 1.78 & 58.44 & 52.75 \\
\hline \multicolumn{2}{|r|}{ Initial value } & 1.51 & 0.14 & 1.25 & 50.90 & 47.00 \\
\hline \multicolumn{2}{|c|}{$\mathrm{SE}(\mathrm{m}) \pm$} & 0.034 & 0.017 & 0.028 & 0.64 & 0.56 \\
\hline \multicolumn{2}{|c|}{ C.D. at $5 \%$} & 0.098 & 0.048 & 0.080 & 1.81 & 1.57 \\
\hline
\end{tabular}




\section{Nitrogen content in Safflower}

The data presented in Table 6 minimum nitrogen content in seed and straw of safflower was observe in treatment $\left(\mathrm{T}_{2}\right)$ only incorporation of crop residue @ $2 \mathrm{t} \mathrm{ha}^{-1}(2.39$ and $1.37 \%$ ) and significantly increased the concentration of nitrogen in seed and straw (2.39 and $1.37 \%)$ under treatment $\left(\mathrm{T}_{1}\right)$ as influenced by 100 per RD of NPK and it was found statistically at par with treatment $\mathrm{T}_{7}$ (2.37 and $1.35 \%$ ) in combination with by 50 percent RD of NPK+ PSB $10 \mathrm{~kg} \mathrm{ha}^{-1}+$ crop residue@2 $\mathrm{tha}^{-1}+$ alkali water irrigation passed through gypsum bed $(30 \mathrm{~cm}$ thickness).

\section{Phosphorus content in Safflower}

The data related to phosphorus in safflower seed was found varied from (0.68 to $0.50 \%)$ and straw $(0.23$ to $0.13 \%)$ are presented in Table 6 . The lowest phosphorus content seed and straw (0.68 and $0.23 \%)$ was observed in treatment $\mathrm{T}_{2}$ due to incorporation of crop residue@2 $\mathrm{t} \mathrm{ha}^{-1}$. A significantly increased highest $\mathrm{P}$ content in seed and straw (0.68 and $0.23 \%$ ) under 100 per cent RD of NPK without incorporation crop residue. As regarded total $\mathrm{P}$ content significantly more in treatment $T_{1}(0.68$ and 0.23$)$ as influenced by 100 per cent RD of NPK without incorporation crop residue followed by treatment $\mathrm{T}_{7}(0.64$ and $0.21 \%)$ due to application of 50 per cent RD of NPK+ PSB $10 \mathrm{~kg} \mathrm{ha}^{-1}+$ crop residue @ $2 \mathrm{ha}^{-1}+$ alkali water irrigation passed through gypsum bed (30 cm thickness).

\section{Potassium content in Safflower}

From the data (Table 6) it is clearly observed that the highest concentration of potassium in seed and straw (0.89 and $1.72 \%)$ was noticed in the treatment $\left(\mathrm{T}_{1}\right)$ receiving under 100 per cent RD of NPK, followed by treatment $\left(\mathrm{T}_{7}\right)$ seed and straw (0.87 and $1.70 \%)$ in combination with 50 per cent RD of NPK+ PSB $10 \mathrm{~kg} \mathrm{ha}^{-1}+$ crop residue @ $2 \mathrm{ha}^{-1}+$ alkali water irrigation passed through gypsum bed $(30 \mathrm{~cm}$ thickness). The lowest potassium content in seed and straw was recorded in treatment $\left(\mathrm{T}_{2}\right)$ due to incorporation crop residue@ $2 \mathrm{tha}^{-1}$.

\section{Nitrogen uptake by Safflower}

Nitrogen plays an important role as it promotes vegetative growth and induces dark green colour to plants. Magnitude of nitrogen fixation and available nutrient in soil exert a great bearing on growth of crop. The data pertaining to uptake of nitrogen by safflower seed as influenced by various treatments are presented in Table 7. The highest $\mathrm{N}$ uptake by safflower grain in treatment $\mathrm{T}_{1}(28.68 \mathrm{~kg} \mathrm{~N}$ $\left.\mathrm{ha}^{-1}\right)$ and straw $\left(22.09 \mathrm{~kg} \mathrm{~N} \mathrm{ha}^{-1}\right)$ consisting 100 per cent RD of NPK without incorporation crop residue and it was found at par with treatment $\mathrm{T}_{7}$ (grain $27.62 \mathrm{~kg} \mathrm{~N} \mathrm{ha}^{-1}$ ) and (straw $22.98 \mathrm{~kg} \mathrm{~N}^{-1}$ ) 50 per cent RD of NPK+ PSB $10 \mathrm{~kg} \mathrm{ha}^{-1}+$ crop residue @ $2 \mathrm{ha}^{-1}$ + alkali water irrigation passed through gypsum bed (30 cm thickness). Lowest nitrogen uptake by safflower seed was recorded in treatment $\mathrm{T}_{2}$ (grain $8.75 \mathrm{~kg} \mathrm{~N}$ ha ${ }^{1}$ ) and (straw $11.57 \mathrm{~kg} \mathrm{~N} \mathrm{ha}^{-1}$ ) as influenced by incorporation of crop residue.

\section{Uptake of phosphorus by Safflower}

The data reflected that results of $\mathrm{P}$ uptake by safflower seed and straw significantly influenced by different treatments. Highest $P$ uptake by seed in treatment $\mathrm{T}_{1}$ (seed $7.97 \mathrm{~kg}$ $\mathrm{P} \mathrm{ha}^{-1}$ ) and (straw $3.71 \mathrm{~kg} \mathrm{P} \mathrm{ha}^{-1}$ ) was recorded under 100 per cent RD of NPK without incorporation crop residue and it was found at par with treatment $\mathrm{T}_{7}$ (seed $7.42 \mathrm{~kg} \mathrm{P}$ $\mathrm{ha}^{-1}$ ) and (straw3.25 $\mathrm{kg} \mathrm{P} \mathrm{ha}^{-1}$ ) as influenced by 50 per cent RD of NPK+ PSB $10 \mathrm{~kg} \mathrm{ha}^{-1}+$ crop residue @ 2 ha $^{-1}+$ alkali water irrigation 
passed through gypsum bed $(30 \mathrm{~cm}$ thickness). The lowest $\mathrm{P}$ uptake was recorded in treatment $\mathrm{T}_{2}$ (seed2.13 kg $\mathrm{P} \mathrm{ha}{ }^{-1}$ ) and (straw $1.25 \mathrm{~kg} \mathrm{P} \mathrm{ha}^{-1}$ ) due to Incorporation of crop residue@ $2 \mathrm{t} \mathrm{ha}^{-1}$.

\section{Potassium uptake}

The data potassium uptake by seed and straw safflower was significantly influenced by various treatments. Potassium uptake by varied. The highest potassium uptake by seed found in $\mathrm{T}_{1}\left(10.43 \mathrm{~kg} \mathrm{~K} \mathrm{ha}{ }^{-1}\right)$ and straw (27.75 $\mathrm{kg} \mathrm{K} \mathrm{ha}^{-1}$ ) as influenced by 100 per cent RD of NPK without incorporation crop residue, and it was found at par with treatment $\mathrm{T}_{7}$ (seed $10.08 \mathrm{~kg} \mathrm{~K} \mathrm{ha}^{-1}$ ) and (straw $26.76 \mathrm{~kg}$ $\mathrm{K} \mathrm{ha}^{-1}$ ) received under 50 per cent $\mathrm{RD}$ of NPK+ PSB $10 \mathrm{~kg} \mathrm{ha}^{-1}+$ crop residue @ 2 ha $^{-1}$ + alkali water irrigation passed through gypsum bed (30 cm thickness). The lowest potassium uptake recorded in treatment $T_{2}$ (3.18 $\mathrm{kg} \mathrm{K} \mathrm{ha}^{-1}$ ) as influenced by incorporation of crop residues@ $2 \mathrm{tha}^{-1}$. The lowest potassium uptake in treatment $\mathrm{T}_{2}$ (seed 3.18) and (straw $14.41 \mathrm{~kg} \mathrm{~K} \mathrm{ha}^{-1}$ ) due to Incorporation of crop residue @ $2 \mathrm{t} \mathrm{ha}^{-1}$.

\section{Bulk Density}

The increase in bulk density of Sodic Haplusters with increasing depth of pedon may be ascribed to increasing the compactness of soils at lower depth and reflected ill drained nature of soil which rendered salt leaching rather difficult. In order to reduce the compactness and the alkalinity of irrigation water and to improving the physical properties of soil, crop residue was incorporation with chemical fertilizer in soil and through dissolution gypsum in alkali water and results obtained pertaining to bulk density are show in table 8. The data regarding bulk density of soil as influence by crop residue, chemical fertilizer and alkali water irrigation passed through gypsum bed were found in the rage 1.39 to $1.51 \mathrm{Mgm}^{-3}$. The maximum in bulk density of soil was found in treatment $\mathrm{T}_{7}(1.39 \mathrm{Mg} \mathrm{M}-3)$ the application with combination 50 per cent recommended dose of NPK + PSB $10 \mathrm{~kg} \mathrm{ha}^{-1}$ + crop residue @ $2 \mathrm{t} \mathrm{ha}^{-1}+$ alkali water passed through gypsum bed (30 cm thickness) and it was found at par with the treatments $\mathrm{T}_{6}, \mathrm{~T}_{4}$, $\mathrm{T}_{3}$ and $\mathrm{T}_{5}$, where incorporations of crop residue was done.

\section{Hydraulic conductivity}

The indicate that saturated hydraulic conductivity of soil in all the treatments was found to decreased with depth. The hydraulic conductivity as affected by various treatments was found in the range 0.15 to $0.33 \mathrm{~cm} \mathrm{hr}^{-1}$. The significantly increase the hydraulic conductivity $\left(0.33 \mathrm{~cm} \mathrm{hr}^{-1}\right)$ in treatment $\mathrm{T}_{7}$ i.e. application of 50 per cent recommended dose of NPK+ PSB $10 \mathrm{~kg} \mathrm{ha}^{-1}$ + crop residue @ $2 \mathrm{t}$ $\mathrm{ha}^{-1}$ and alkali water passed through gypsum bed of $30 \mathrm{~cm}$ thickness while irrigation to safflower under Sodic Haplusterts which was followed by treatment $\mathrm{T}_{6}\left(0.30 \mathrm{~cm} \mathrm{hr}^{-1}\right)$ i.e. 50 per cent recommended dose of NPK + PSB $10 \mathrm{~kg} \mathrm{ha}{ }^{-1}+$ crop residue @ $2 \mathrm{t} \mathrm{ha}^{-1}$. Indicating the significance of incorporation ofo crop residue and alkali water passed through gypsum bed of $30 \mathrm{~cm}$ thickness under soidic Haplusterts improvement in sodic characteristics of soil.

\section{Infiltration rate}

Infiltration rate under different treatments was found high initially and it was decreased with passage of time at 10 minute interval. The maximum infiltration was recorded treatment $\mathrm{T}_{7}\left(1.78 \mathrm{~cm} \mathrm{hr}^{-1}\right)$ in combination with 50 per cent RD of NPK + PSB $10 \mathrm{~kg} \mathrm{ha}^{-1}+$ crop residue@2 $\mathrm{t} \mathrm{ha}^{-1}+$ alkali water irrigation passed through gypsum bed of $30 \mathrm{~cm}$ thickness. However, treatment $\mathrm{T}_{6}$ recorded infiltration $\left(1.72 \mathrm{~cm} \mathrm{hr}^{-1}\right)$ influenced by 50 per 
cent RD of NPK + PSB $10 \mathrm{~kg} \mathrm{ha}^{-1}+$ crop residue@2 $\mathrm{t} \mathrm{ha}^{-1}$ and it was found statistically at par to each other. Indicate that incorporation of crop residu in combination with fertilizer application an improvement in infiltration rat of soil Badanur et al., (1990) and Reddy et al., (2002). Lowest infiltration rate was found in treatment $\mathrm{T}_{1}\left(1.23 \mathrm{~cm} \mathrm{hr}^{-1}\right)$ due to application of 100 per cent recommended dose of NPK without incorporation of crop residue.

\section{Maximum water holding capacity}

A significantly higher value of maximum water holding capacity was observed in treatment $\mathrm{T}_{7}(58.44 \%)$ receiving under 50 per cent recommended dose of NPK + PSB $10 \mathrm{~kg}$ $\mathrm{ha}^{-1}+$ crop residue @ $2 \mathrm{t} \mathrm{ha}^{-1}+$ alkali water irrigation passed through gypsum bed of 30 $\mathrm{cm}$ thickness, and it was found at par with treatment $\mathrm{T}_{6}(57.15 \%)$ an application of 50 per cent recommended dose of NPK + PSB $10 \mathrm{~kg}$ $\mathrm{ha}^{-1}+$ crop residue @ $2 \mathrm{t} \mathrm{ha}^{-1}$. The lowest value of maximum water holding capacity was observed under treatment $\mathrm{T}_{1}(51.35 \%)$ with 100 per cent recommended dose of NPK without incorporation of crop residue only. Incorporation of crop residue decreased the bulk density and increased the soil porosity thus significantly enhanced the water holding capacity of soil (Das et al., 2001).

\section{Water stable aggregate}

The data revealed that, the value of per cent water stable aggregates $>0.25 \mathrm{~mm}$ were found statistically significant. Per cent water stable aggregate $>0.25 \mathrm{~mm}$ found in the range of 46.23 to 52.75 per cent respectively. The highest value per cent water stable aggregate was recorded in treatment $\mathrm{T}_{7}$ (52.75) receiving 50 per cent recommended dose NPK + PSB $10 \mathrm{~kg} \mathrm{ha}^{-1}+$ crop residue @ $2 \mathrm{t} \mathrm{ha}^{-1}+$ alkali water passed through gypsum bed of $30 \mathrm{~cm}$ thickness for irrigation, and it was found statistically at par with treatment $\mathrm{T}_{6}(51.56 \%)$ influenced by 50 per cent recommended dose NPK + PSB $10 \mathrm{~kg} \mathrm{ha}^{-1}+$ crop residue. The per cent water stable aggregates found decreased in treatment $T_{1}$ (46.23) receiving 100 per cent recommended dose of NPK without incorporation of crop residue. The reduction in water stable aggregate with application of fertilizer might be attributed to the deteriorative action of fertilizer nitrogen on soil structure (Bellakki, 1994). Incorporation of crop residues enhanced biological activity in the soil and helps in soil aggregation. The crop residues after their incorporation in soil undergo decomposition and results in addition of nutrients as well as sobulization of soil nutrients due to organic acid especially in Sodic Vertisols of Purna Valley soils and improves all physical properties e.g. decrease in bulk density, increase infiltration rate, hydraulic conductivity of soil and also improves soil aggregates and maximum water holding capacity.

\section{References}

Ali, W., and R.K.Pathak, 1991. Effect sodicity levels on growth, nutrient status and chlorophyll content in Phalsa (Grewia subnaequalis). Indian J. Agric. Sci., 61 (1): 25-56.

Badanur, V.P., M.A. Bellakki; S.I. Tolanur, 2000. Incorporation of sunflower crop residues for integrated nutrient management of rabi sorghum in Vertisol. Karnataka J. Agric. Sci., 13(3): 733-734.

Bellakki, M.A., and V.P. Badanur, 1994. Effect of crop residue incorporation on physical and chemical properties of a Vertisol and yield of sorghum. Indian Soc. Soil Sci., 42:533-535.

Das, K., D.N. Medhi and B. Guha, 2001. Recycling effect of crop residue with chemical fertilizers on physio-chemical 
proprieties of soil and rice (Oryza sativa) yield. Indian J. Agronomy, 46(4): 648-653.

Gomez, K.A., and A.A. Gomez, 1984. Randomized Block Design in Statistical procedure for agriculture research publisher by A Wiley Inter Science, USA: 621-635.

Government of Maharashtra, 2001. Vidarbhateel Purna Khoryateel Khare Paanee Patta Samasya Nivaranartha Uchchadhikar Samitacha Ahawaal, April-May 2001. pp. 11.

Huber, S.C., 1985. USDA-NCSU Raleigh. Biochemical basis for effects of $\mathrm{K}$ deficiency on assimilate exports rate and accumulation of soluble sugars in soybean leaves. Potash Review Sub., 13: 9 .

Jackson, M.L., 1967. Soil Chemical Analysis. Prentice Hall of India Pvt. Ltd. New Delhi.

Paliwal, K.V., G.L. Maliwal and G.C. Nanawati, 1975. Effect of bicarbonate rich irrigation water on the yield and nutrient uptake in cotton (Gossypium spp.) and linseed (Linum usitatissimum). Ann. Arid Zone, 17(2): 164-174.

Poonia, S.R., and D.R. Bhumbla, 1973a. Effect of gypsum and calcium carbonate on plant yield and chemical composition and calcium availability in a non-saline sodic soil. Pl. Soil. 38: 7180.

Poonia, S.R., and D.R. Bhumbla, $1973 b$. Availability of $\mathrm{Ca}$ from $\mathrm{CaSO}_{4}$ in a highly saline-sodic soil. Pl. Soil. 38: 675-678.
Rasal, P.H., B.R. Jadar; R.B. Nazirkar, H.B. Kalbhor and K.B. Pawar, 2003 . Recycling of crop residues in sequence cropping. J. Maharashtra Agric. Univ., 28(1): 84-87.

Reddy, G.R., G.V. Malewar, 2002. Effect of crop residue incorporation and tillage operations on soil properties of Vertisols under rainfed agriculture. Indian J. Dryland Agric. Res. and Development, 17(1): 55-58.

Sagare, B. N., S.K. Thakre and V.P. Babhulkar, 2000. Salt affected soils of Purna valley in Vidarbha. Bull 83, pp. 1-60, DR. PDKV, Akola M.S. (India).

Singh, R. A., 1980. Soil Physical analysis, Kalyani Publisher, New Dilhi: 53-60

Subbarao, N.S., 1987. Biofertilizer in Agriculture, IBH Co. PVt. Ltd. New Delhi.

Swamy, K., Ramalinga and K. Veerabhandra Rao, 1991. Reduction of adverse effects of sodic water on greengram (Phaseolus radiata) by treatments of soil and water with gypsum. Indian J. Agric. Sci. 61(10): 763-765.

Velayutam, M., and T. Bhattaacharyya, 2000. Soil Resource Management Natural Resource Management for Agricultural Production in India. (J. S. P. Yadav and G.B. Singh, ed.), pp.1-136. Int. Conf. on Management Natural Resource for Sustainable Agricultural Production in the $21^{\text {st }}$ Century, Feb.14-18, New Delhi, India.

Waisel, Y., 1962. The effect of $\mathrm{Ca}$ on the uptake of monvalent ions by exclised barley roots. Pl. Physiol. 15: 709-724.

\section{How to cite this article:}

Bhowate R. T. and Bansod P. H. 2017. Effect of Crop Residues Incorporation on Physical Properties and Yield of Greengram-Safflower Crop Sequence under Sodic Haplusterts. Int.J.Curr.Microbiol.App.Sci. 6(9): 3717-3730. doi: https://doi.org/10.20546/ijcmas.2017.609.459 